\title{
Komposisi Jenis, Struktur Komunitas, dan Keanekaragaman Mangrove Asosiasi Langge Kabupaten Gorontalo Utara-Provinsi Gorontalo
}

\author{
Sukirman Rahim dan Dewi Wahyuni K.Baderan
}

\author{
${ }^{1}$ Kependudukan dan Lingkungan Hidup, Pascasarjana Universitas Negeri Gorontalo,; e-mail: \\ sumirmanrahim@gmail.com; dewi.baderan@ung.ac.id
}

\begin{abstract}
ABSTRAK
Hutan mangrove Langge yang terdapat di Kecamatan Anggrek Kabupaten Gorontalo Utara memiliki keunikan dari pola zonasi dan keanekaragaman jenis. Hal ini yang menjadikan hutan mangrove di kawasan tersebut sebagai objek wisata tracking mangrove yang dikenal dengan nama "mangrove in love. Hutan mangrove memiliki berbagai fungsi ekologis yang sangat kompleks yakni sebagai daerah pemijahan (spawing ground), tempat asuhan (nursery ground), dan tempat mencari makan (feeding ground) biota laut yang beraneka jenis dan memiliki fungsi ekonomis diantaranya buah mangrove dapat diolah menjadi berbagai produk kue dan sumber pangan alternatif pengganti beras. Penelitian ini bertujuan untuk : 1) untuk menganalisis komposisi jenis mangrove asosiasi; 2) untuk mengkaji struktur komunitas dari hutan mangrove Langge; dan 3) nilai Indeks Keanekaragaman. Adapun metode yang digunakan dalam penelitian ini adalah metode jalur berpetak (kombinasi plot dan transek). Jumlah spesies yang ditemukan akan dilihat untuk menjadi dasar penentuan komposisi jenis. Untuk pengkuran struktur komunitas mangrove dengan melakukan perhitungan terhadap Kerapatan Relatif (KR) dan Frekuensi Relatif (FR). Selanjutnya data yang didapatkan ditabulasikan untuk memperoleh nilai Indeks Nilai Penting (INP). Perhitungan keanekaragaman jenis menggunakan rumus (Sannon-wienner). Hasil penelitian menemukan 12 spesies tumbuhan mangrove asosiasi yakni Acanthus spinosus, Chromolaena odorata, Crassocephalum sp, Calotropis gigantean, Ipomea pes-caprae, Ricinus communis Excoecaria agallocha, Scaevola taccada, Spinifex littoreus, Terminalia catappa, Derris trifoliate dan Nypa fruticans. Mangrove asosiasi yang ditemukan tersebut termasuk dalam divisi yakni Magnoliophyta, dua kelas yakni magnoliopsida dan Liliopsida, sepuluh ordo yakni Scrophulariales, Asterales, Gentianales, Solanales, Euphorbiales, Asterales, Poales, Myrales, Fabales dan Arecales. Termasuk dalam sepuluh famili yakni Acanthaceae, Asteraceae, Apocynaceae, Convolvulaceae, Euphorbiaceae, Goodeniaceae, Poaceae, Combretaceae, Fabaceae dan Arecaceae. Struktur komunitas menunjukkan Chromolaena odorata memiliki nilai INP sebesar 33,2\%, Kerapatan Relatif sebesar 24,91\%, dan Frekuensi Relatif sebesar 8,33\%. Spesies dengan nilai INP terendah dimiliki oleh Nypa fruticans yaitu sebesar 9,14\%, Kerapatan Relatif sebesar 0,81\%, dan Frekuensi Relatif sebesar 8,33\%. Nilai Indeks Keanekaragaman (H') mangrove asosiasi sebesar 2,175 dan termasuk dalam kriteria tingkat keanekaragaman sedang. Data yang diperoleh ini dapat digunakan dalam pengelolaan hutan mangrove di Gorontalo Utara serta dapat menjadi database dalam usaha konservasi mangrove guna mengurangi efek pemanasan global.
\end{abstract}

Kata kunci: Komposisi, INP, Keanekaragaman, Mangrove Asosiasi

\begin{abstract}
Langge mangrove forest located in the District of North Gorontalo District Orchid has a uniqueness of zoning patterns and keanekragaman types. This is what makes the mangrove forests in the region as a tourist attraction tracking mangrove known as the "mangrove in love. Mangrove forests have a variety of ecological functions is very complex which is a spawning area (spawing ground), point of care (nursery grounds), and foraging (feeding ground) various types of marine life and has the economic function of which pieces of mangrove can be processed into various products cake and alternative food sources instead of rice. This study aims to: 1) to determine the association of mangrove species composition; 2) to determine the community structure of mangrove forests Langge; and 3) the value of diversity index. The method used in this study is a terraced path method (combination of plots and transects). The composition of the types of views based on the number of species found. For sizing mangrove community structure by calculating the Relative Density (KR) and Relative Frequency (FR). Then the data obtained are tabulated to get the value of Importance Value Index (IVI). Calculation of species diversity using the formula (Sannon-wienner). The study found an association of twelve species of mangrove plants and the relative dominance (DR), then the data obtained are tabulated to get the value of Importance Value Index (IVI). Calculation of species diversity using the formula (Sannon-wienner). The study found an association of eight species of mangrove plants and the relative dominance (DR), then the data obtained are tabulated to get the value of Importance Value Index (IVI). Calculation of species diversity using the formula (Sannon-wienner). The study found an association of twelve species of mangrove plantsnamely Acanthus spinosus, Chromolaena odorata, Crassocephalum sp, Calotropis gigantean, Ipomea pes-caprae, Ricinus communis Excoecaria agallocha, Scaevola taccada, Spinifex littoreus, Terminalia catappa, Derris trifoliate dan Nypa fruticans. The mangrove associations found included in the divisions namely Magnoliophyta, two classes namely magnoliopsida and


Liliopsida, ten orders namely Scrophulariales, Asterales, Gentianales, Solanales, Euphorbiales, Asterales, Poales, Myrales, Fabales and Arecales. Included in ten families are Acanthaceae, Asteraceae, Apocynaceae, Convolvulaceae, Euphorbiaceae, Goodeniaceae, Poaceae, Combretaceae, Fabaceae and Arecaceae. Community structure showed Chromolaena odorata has a value of IVI of 33,2\%, amounting to $24,91 \%$ Relative Density and Relative Frequency of 8,33\%. The species with the lowest IVI owned by Nypa fruticans that is equal to 9,14\%, 0,81\% Relative Density and Relative Frequency of 8,33\%. Values Diversity Index ( $\left.\mathrm{H}^{\prime}\right)$ at 2.175 and mangrove associates included in the criteria for a medium level of diversity. The data obtained can be used in the management of mangrove forests in North Gorontalo and can be a database of mangrove conservation efforts to reduce the effects of global warming.

Keywords: Composition, INP, Diversity, Mangrove Association

Citation: Rahim, Sukirman dan Dewi Wahyuni K.Baderan (2019). Komposisi Jenis, Struktur Komunitas, dan Keanekaragaman Mangrove Asosiasi Langge Kabupaten Gorontalo Utara-Provinsi Gorontalo. Jurnal Ilmu Lingkungan, 17(1),181-189, doi:10.14710/jil.17.1.181-188

\section{Pendahuluan}

Kawasan pesisir dan laut merupakan sebuah ekosistem yang terpadu dan saling berhubungan satu sama lain, sehingga memiliki korelasi timbal balik. Di dalam sebuah ekosistem pesisir terjadi pertukaran materi dan transformasi energi yang berlangsung dalam sistem tersebut maupun dengan komponenkomponen sistem luar lainnya. Menurut Bengen (2004), kelestarian sumber daya alam sangat bergantung pada kelangsungan fungsi sebuah ekosistem yang terlibat di dalamnya. Salah satu ekosistem utama di wilayah pesisir dan lautan adalah ekosistem mangrove.

Ekosistem mangrove memiliki vegetasi yang memberikan manfaat dan fungsi yakni mengurangi resiko abrasi (Hilmi et al, 2014), kemampuan untuk meredam gelombang pasang dan resiko tsunami (Massel et al, 1999; Hilmi et al, 2019; Kerr et al, 2006; Chang et al, 2019), habitat berbagai mikroorganisme (Elison, 2008; Calabon et al, 2019), sebagai sumber pangan (Baderan et al, 2014).

Provinsi Gorontalo mempunyai kawasan mangrove yang luas salah satu kawasan mangrove tersebut berada di desa Langge Kecamatan Anggrek, Kabupaten Gorontalo Utara, Provinsi Gorontalo. Adanya erbagai fungsi dan manfaat yang dihasilkan oleh hutan Mangrove, menjadikan ekosistem tersebut sebagai komponen penting yang mendukung kelangsungan hidup yang ada di wilayah Kecamatan Anggrek itu sendiri. Kawasan hutan mangrove yang ada di Langge memiliki berbagai jenis vegetasi yang memperkaya keanekaragaman hayati, salah satunya vegetasi mangrove asosiasi (CCD-IPAD, 2013). Mangrove asosiasi adalah vegetasi yang tumbuh ke arah darat di belakang zona mangrove sejati, tumbuhan yang toleran terhadap salinitas, yang dimana hal tersebut tidak ditemukan secara eksklusif di hutan mangrove dan hanya merupakan vegetasi transisi ke daratan atau lautan, akan tetapi dapat berinteraksi dengan mangrove sejati. (Wang et. al, 2010; De Sauza el.al, 2016; Hossain \& Nuruddin, 2016; Annisa et. al, 2017, Soares et, al 2017).

Keberadaan mangrove asosiasi yang ada di Desa Langge masih belum diketahui jenis-jenisnya, hal ini juga dibuktikan dengan data base dan penelitian- penelitian mengenai keanekaragaman mangrove asosiasi yang masih sedikit. Berdasarkan uraian latar belakang diatas, maka informasi mengenai komposisi, struktur komunitas dan keanekaragaman mangrove asosiasi di Desa Langge Kecamatan Anggrek sangat diperlukan, agar dapat dijadikan sebagai data awal dalam upaya pelestarian mangrove asosiasi baik di Desa Langge maupun di daerah lain di Indonesia dapat lebih ditingkatkan lagi.

\section{Metode Penelitian}

Area kajian di kawasan mangrove Desa Langge, Kecamatan Anggrek, Kabupaten Gorontalo Utara, Provinsi Gorontalo. Secara geografis wilayah penelitian terletak antara koordinat $00^{\circ} .48^{\prime} .28,809^{\prime \prime}$ $\mathrm{N}$ dan 1220.50'. 24,836" E. Secara administrasi wilayah penelitian berbatasan dengan : Sebelah Utara berbatasan dengan Laut Sulawesi, Sebelah Timur berbatasan dengan Desa Tutuwoto, Sebelah Selatan berbatasan dengan Desa Tolongio, Sebelah Barat berbatasan dengan Desa Ilodulunga. Posisi geografis wilayah kajian disajikan pada peta (Gambar 1).

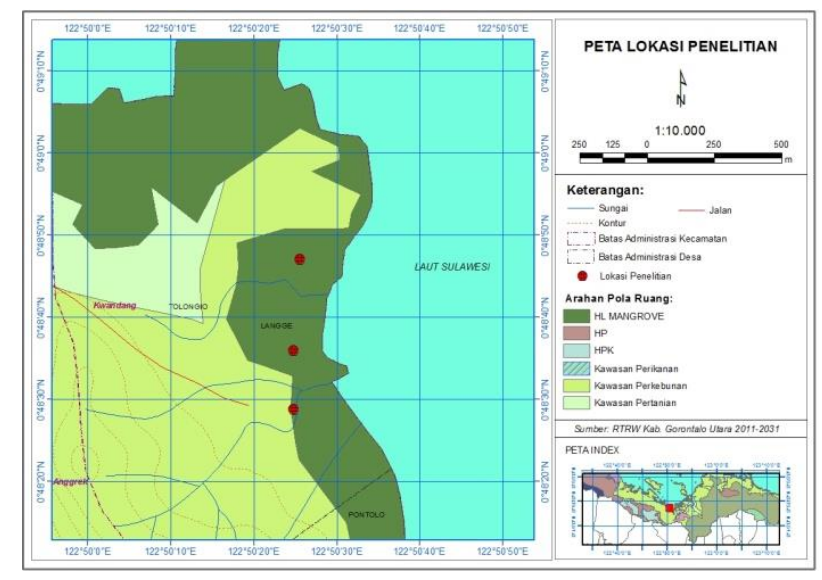

Gambar 1. Lokasi penelitian desa Langge, Kecamatan Anggrek, Kabupaten Gorontalo Utara

Pengambilan data komposisi mangrove asosiasi menggunakan metode kombinasi jalur berpetak. Setiap jalur transek dibuat tegak lurus ke arah daratan dari pantai memotong komunitas mangrove formasi terdepan (tepi laut) sampai formasi paling 
belakang (berbatasan dengan daratan). Jalur transek ditempatkan secara purposive berdasarkan pemanfaatan kawasan. Inventarisasi strata pertumbuhan mangrove asosiasi dicatat pada setiap jalur terbagi ke dalam petak ukuran $5 \mathrm{~m}$ x $5 \mathrm{~m}$. (Mueller dan Ellenberg, 1974). Identifikasi bagi jenisjenis mangrove asosiasi yang diketahui langsung dilakukan di setiap petak yang diamati untuk mendapatkan data tentang komposisi jenis. Spesimen herbarium dibuat untuk jenis mangrove yang berum berhasil diidentifikasi dengan cara diambil contoh daun, bunga dan buah. Bagian tersebut kemudian diberi kode label dan catatan mengenai kondisi lokasi, habitat dan manfaat lalu dirapikan dan dibungkus dengan kertas koran 40 x $50 \mathrm{~cm}$ kemudian di siramkan cairan spritus dengan tujuan untuk pengawetan (Sidiyasa et al., 2004). Kemudian, spesimen dijemur di bawah terik matahari sampai terlihat kering. Proses identifikasi spesimen selanjutnya dilakukan dengan membandingkan karakter morfologi jenis mangrove yang ditemukan dengan merujuk pada rujukan - rujukan, seperti Noor et al., (2012).

\section{Analisis Data}

\section{Struktur Komunitas}

Analisis struktur komunitas dengan melakukan perhitungan terhadap Kerapatan Relatif (KR) dan Frekuensi Relatif (KR). Perhitungan Dominansi Relatif (DR) tidak perlu dilakukan karena diameter mangrove asosiasi tidak diukur. Kemudian seluruh data yang didapatkan ditabulasikan untuk memperoleh indeks nilai penting (INP).

$$
\begin{aligned}
\mathrm{INP} & =\mathrm{KR}+\mathrm{FR} \\
\mathrm{K} & =\frac{\text { Total individu suatu spesies }}{\text { Luas transek pengamatan }} \\
\mathrm{KR} & =\frac{\text { Kerapatan suatu spesies }}{\text { Kerapatan seluruh spesies }} \times 100 \% \\
\mathrm{~F} & =\frac{\text { Jumlah transek ditemukannya suatu spesies }}{\text { Total jumlah seluruh transek }} \\
\mathrm{FR} & =\frac{\text { Frekuensisuatu spesies }}{\text { Total frekuensi seluruh }}
\end{aligned}
$$

Keterangan:

$\begin{array}{ll}\text { INP } & =\text { Indeks Nilai Penting } \\ \mathrm{K} & =\text { Kerapatan } \\ \mathrm{KR} & =\text { Kerapatan Relatif } \\ \mathrm{F} & =\text { Frekuensi } \\ \mathrm{FR} & =\text { Frekuensi Relatif }\end{array}$

Keanekaragaman Spesies

Data keanekaragaman spesies mangrove asosiasi diketahui dengan menggunakan Indeks Keanekaragaman $\left(\mathrm{H}^{t}\right)$ Shannon-Wienner (Fachrul, 2007).

$$
\begin{aligned}
\mathrm{H}^{s}= & -\sum_{\mathrm{i}=1}^{5} \text { pi } \ln \text { pi } \\
& \text { di mana: } \mathrm{pi}=\frac{\mathrm{ni}}{\mathrm{N}}
\end{aligned}
$$

Keterangan

$\mathrm{H}^{\prime}$ = Indeks diversitas Shannon-Wienner

$S=$ Jumlah spesies

$\mathrm{Ni}=$ Jumlah individu dalam satu spesies

$L n=$ Logaritma natural

$\mathrm{N}$ = Jumlah total individu spesies yang ditemukan

\section{Hasil dan Pembahasan}

Gambaran Umum Lokasi Penelitian

Langge merupakan salah satu Desa yang berada di Kecamatan Anggrek Kabupaten Gorontalo Utara, Desa Langge secara adminstratif terbagi atas 3 Dusun yaitu Dusun Pantai, Dusun Tengah, dan Dusun Polowa yang secara keseluruhan memiliki luas $573,45 \mathrm{Ha}$. Sedangkan untuk hutan mangrove di Desa Langge seluas $40 \mathrm{Ha}$. Desa Langge merupakan desa yang dimekarkan dari desa Tolongio pada tahun 2011, yang sebagian besar penduduknya adalah nelayan dan petani tradisional. Desa Langge mempunyai luas wilayah $\pm 543,5$ Ha dengan jumlah penduduk pertahun 2015 adalah sekitar 475 jiwa dengan jumlah KK yaitu 123 KK (Profil Desa Langge, 2015).

Desa Langge memiliki kawasan hutan mangrove yang luas dan masih dalam kondisi yang baik dan belum mengalami kerusakan yang signifikan, hal ini sesuai dengan data Dinas Kehutanan Pertambangan dan Energi setempat tahun 2015 luas hutan mangrove di daerah ini mencapai 5.483,93 ha. Luasan yang mengalami rusak berat mencapai 2.902 ha, rusak ringan mencapai 97 ha dan yang tidak rusak mencapai 2.484 ha. Kawasan mangrove di Desa Langge pada tahun 2017 mulai dibangun tempat wisata tracking mangrove. Secara geografis, desa Langge terletak paling ujung yang berbatasan langsung dengan Kecamatan Kwandang. Desa Langge memiliki suhu $\pm 30^{\circ} \mathrm{C}$ dengan curah hujan $\pm 2000 / 3000 \mathrm{Mm}$.

\section{Komposisi Jenis Mangrove Asosiasi}

Berdasarkan data komposisi jenis mangrove asosiasi, di kawasan ini di temukan sebanyak 12 spesies tumbuhan mangrove asosiasi yakni Acanthus spinosus, Chromolaena odorata, Crassocephalum sp, Calotropis gigantean, Ipomea pes-caprae, Ricinus communis Excoecaria agallocha, Scaevola taccada, Spinifex littoreus, Terminalia catappa, Derris trifoliate dan Nypa fruticans. Mangrove asosiasi yang ditemukan tersebut termasuk dalam divisi yakni Magnoliophyta, dua kelas yakni magnoliopsida dan Liliopsida, sepuluh ordo yakni Scrophulariales, Asterales, Gentianales, 
Solanales, Euphorbiales, Asterales, Poales, Myrales, Fabales dan Arecales. Termasuk dalam sepuluh famili yakni Acanthaceae, Asteraceae, Apocynaceae, Convolvulaceae, Euphorbiaceae, Goodeniaceae, Poaceae, Combretaceae, Fabaceae dan Arecaceae. Jenis mangrove asosiasi yang ditemukan dapat dilihat di Tabel 1.

\section{Struktur Komunitas}

Struktur komunitas didasarkan pada pengukuran beberapa parameter, yaitu kerapatan, frekuensi, dan dominansi jenis serta indeks nilai penting yang merupakan gabungan dari dari hasil perhitungan nilai relatif dari ketiga parameter tersebut. Namun pada perhitungan indeks nilai penting mangrove asosiasi, dominansi spesies tidak dihitung. Tabel 2. menunjukkan hasil perhitungan yang memperlihatkan jenis tumbuhan yang mendominasi kawasan dengan indeks nilai penting di atas $30 \%$.

Tabel 1. Komposisi Jenis Mangrove Asosiasi di Desa Langge Kabupaten Gorontalo Utara

\begin{tabular}{|c|c|c|c|c|c|c|}
\hline Regnum & Divisi & Kelas & Ordo & Famili & Genus & Spesies \\
\hline \multirow{12}{*}{ Plantae } & \multirow{12}{*}{ Magnoliophyta } & \multirow{11}{*}{ Magnoliopsida } & Scrophulariales & Acanthaceae & Acanthus & Acanthus spinosus \\
\hline & & & & & Chromolaena & Chromolaena odorata \\
\hline & & & Asterales & Asteraceae & Crassocephalum & Crassocephalum sp. \\
\hline & & & Gentianales & Apocynaceae & Calotropis & Calotropis gigantea \\
\hline & & & Solanales & Convolvulaceae & Ipomea & Ipomea pes-caprae \\
\hline & & & $\Gamma$ & $\Gamma$ ol & Ricinus & Ricinus communis \\
\hline & & & Eupilorididies & Eupirortidacede & Excoecaria & Excoecaria agallocha \\
\hline & & & Asterales & Goodeniaceae & Scaevola & Scaevola taccada \\
\hline & & & Poales & Poaceae & Spinifex & Spinifex littoreus \\
\hline & & & Myrales & Combretaceae & Terminalia & Terminalia catappa \\
\hline & & & Fabales & Fabaceae & Derris & Derris trifoliata \\
\hline & & Liliopsida & Arecales & Arecaceae & Nypa & Nypa fruticans \\
\hline
\end{tabular}

Tabel 2. Indeks Nilai Penting Mangrove Asosiasi di Desa Langge Kabupaten Gorontalo Utara

\begin{tabular}{|c|c|c|c|c|c|c|}
\hline \multirow[b]{2}{*}{ No } & \multirow[b]{2}{*}{ Spesies } & $\mathbf{K}$ & $\mathbf{K r}$ & $\mathbf{F}$ & Fr & \multirow{2}{*}{ INP (\%) } \\
\hline & & $\left(m^{2}\right)$ & (\%) & (\%) & (\%) & \\
\hline 1 & Chromolaena odorata & 0.22 & 24.91 & 1 & 8.3333 & 33.2 \\
\hline 2 & Derris trifoliata & 0.14 & 16.57 & 1 & 8.3333 & 24.9 \\
\hline 3 & Acanthus spinosus & 0.12 & 13.56 & 1 & 8.3333 & 21.9 \\
\hline 4 & Excoecaria agallocha & 0.11 & 12.17 & 1 & 8.3333 & 20.5 \\
\hline 5 & Ipomea pes-caprae & 0.06 & 6.721 & 1 & 8.3333 & 15.1 \\
\hline 6 & Ricinus communis & 0.05 & 5.678 & 1 & 8.3333 & 14 \\
\hline 7 & Spinifex littoreus & 0.05 & 5.446 & 1 & 8.3333 & 13.8 \\
\hline 8 & Terminalia catappa & 0.04 & 5.098 & 1 & 8.3333 & 13.4 \\
\hline 9 & Calotropis gigantea & 0.04 & 4.171 & 1 & 8.3333 & 12.5 \\
\hline 10 & Scaevola taccada & 0.03 & 3.36 & 1 & 8.3333 & 11.7 \\
\hline 11 & Crassocephalum sp. & 0.01 & 1.506 & 1 & 8.3333 & 9.84 \\
\hline 12 & Nypa fruticans & 0.01 & 0.811 & 1 & 8.3333 & 9.14 \\
\hline
\end{tabular}

Keterangan: K: Kerapatan, KR: Kerapatan Relatif, F: Frekuensi, FR: Frekuensi Relatif, INP:Indeks Nilai Penting

Berdasarkan Tabel 2. menunjukkan beberapa spesies mangrove asosiasi yang menonjol yaitu spesies Chromolaena odorata dengan nilai INP sebesar 33,2 \%, kerapatan relatif sebesar 24,91\%, dan frekuensi relatif sebesar 8,3\%. Spesies dengan INP tertinggi kedua dimiliki oleh spesies Derris trifoliata dengan nilai INP sebesar 24,9\%, kerapatan relatif sebesar $16,57 \%$, dan frekuensi relatif sebesar $8,3 \%$. Spesies dengan nilai INP terendah dimiliki oleh spesies Nypa fruticans yaitu sebesar 9,14 \%, kerapatan relatif sebesar $0,81 \%$, dan frekuensi relatif sebesar 8,3\%. Berdasarkan nilai-nilai ini dapat diketahui spesies Chromolaena odorata merupakan spesies mangrove asosiasi yang dominan di lokasi penelitian. Persentase vegetasi mangrove asosiasi disajikan pada gambar 1 .

Ekosistem hutan mangrove saat ini, mengalami ancaman berupa penebangan, konversi menjadi 
bentuk pemanfaatan lain seperti tambak, kebun, sawah, dan peruntukkan lainnya. Di Indonesia, hutan mangrove cenderung mengalami kerusakan diberbagai wilayah. Hal ini disebabkan oleh dua hal, yakni kerusakan yang timbul dari kekuatan alam dan kerusakan yang timbul dari kegiatan manusia. Kerusakan yang ditimbulkan oleh alam cenderung bersifat alami karena kejadiannya merupakan siklus alam yang nantinya akan membentuk suksesi dan dapat mengembalikan keadaan hutan mangrove pada keadaan baik seperti sebelumnya. Hal ini dikenal sebagai proses suksesi. Sedangkan kerusakan yang ditimbulkan oleh kegiatan manusia dapat mengancam ekosistem hutan mangrove yang dapat memusnahkan ekosistem tersebut. Hal ini terjadi karena tidak adanya sikap hati-hati dari manusia dalam mengambil kekayaan hutan mangrove dengan cara melakukan penebangan habis - habisan hingga terjadi penggundulan. Dengan demikian, spesies flora fauna dan biota tertentu akan mengalami kepunahan apabila keadaan tersebut terus terjadi Selain itu, punahnya flora fauna dan berbagai biota mangrove secara tidak langsung akan berdampak pada kehidupan masyarakat yang menggantungkan hidup pada hutan mangrove.

Spesies mangrove yang terdapat pada lokasi penelitian tumbuh bercampur dalam satu zonasi sehingga terlihat berbeda dengan pola zonasi pada umumnya yang tumbuh di daerah lain. Kelompok mangrove di lokasi penelitian dibagi menjadi dua kelompok yakni mangrove sejati, yakni flora yang hanya terdapat pada ekosistem mangrove dan tidak ditemukan di komunitas terrestrial, berkemampuan membentuk tegakan murni yang secara dominan dapat mencirikan struktur dari suatu komunitas, secara morfologi mempunyai bentuk-bentuk adaptif khusus yakni seperti bentuk akar dan buah, dan mangrove asosiasi yakni jenis tumbuhan yang berasosiasi dengan mangrove sejati. Berdasarkan hasil penelitian yang dilakukan di desa Langge Kecamatan Anggrek Kabupaten Gorontalo Utara ditemukan beranekaragam spesies mangrove asosiasi. Total keseluruhan spesies mangrove asosiasi yang ditemukan di lokasi penelitian adalah sebanyak 12 spesies.

Hasil penelitian menunjukkan bahwa spesies mangrove asosiasi yang dominan ditemukan yaitu spesies Chromolaena odorota dan Derris trifoliata. Chromolaena odorota merupakan spesies yang paling banyak ditemukan di lokasi penelitian, pada lokasi penelitian spesies ini tumbuh subur di tanah berpasir dan pasir berlumpur. Spesies ini sangat cepat tumbuh dan berkembang biak, karena cepatnya perkembangbiakkan dan pertumbuhannya, spesies ini cepat juga membentuk komunitas yang rapat. Menurut pendapat Vanderwoude et al. (2005), spesies ini dapat tumbuh baik pada berbagai jenis tanah dan tumbuh dengan baik di tempat-tempat yang terbuka seperti padang rumput, tanah terlantar dan pinggir-pinggir jalan yang tidak terawat. Derris triploliata ini juga merupakan salah satu spesies mangrove asosiasi yang sering ditemukan dihutan mangrove Desa Langge Kecamatan Anggrek Kabupaten Gorontalo Utara. Spesies ini mampu beradaptasi dengan baik terhadap faktor lingkungan abiotik seperti salinitas dan tekstur tanah, pada lokasi penelitian spesies ini sering ditemukan pada kondisi tanah berlumpur dan salinitas Hal ini sesuai pendapat Utina et al., (2012) bahwa tumbuhan Derris trifoliata merupakan salah satu tumbuhan yang bersifat euryhaline yaitu mampu beradaptasi dengan baik pada bebagai tingkat salinitas dan mampu hidup dengan kondisi tanah berpasir, pasir berlumpur dan berlumpur, akan tetapi spesies ini lebih banyak dijumpai berada pada kondisi tanah berlumpur dengan kisaran pH 5-7,2.

Berdasarkan uraian di atas dari semua spesies mangrove asosiasi yang ditemukan dikawasan mangrove Desa Langge Kecamatan Anggrek Kabupaten Gorontalo Utara dapat dinyatakan bahwa kedua spesies yakni Chromolaena odorota dan Derris trifoliata memberikan kontribusi yang relatif besar pada komunitas mangrove asosiasi dihutan mangrove Desa Langge Kecamatan Anggrek Kabupaten Gorontalo Utara, atau dapat diartikan juga bahwa ketiga spesies ini merupakan vegetasi utama dalam menyusun mangrove asosiasi diwilayah tersebut. Sejalan dengan pendapat Utina et al., (2012) bahwa telah diketahui spesies yang dominan dan tersebar secara luas mampu untuk memanfaatkan kondisi lingkungan dengan baik. Tumbuhan mangrove asosiasi ini umumnya memiliki mekanisme fisiologi tertentu untuk beradaptasi terhadap lingkungan mangrove. Bentuk adaptasi fisiologi ini umumnya terkait dengan adaptasi garam dan adaptasi tehadap tanah yang gembur.

Salah satu faktor lingkungan yang diukur adalah suhu dan $\mathrm{pH}$ tanah, dari masing-masing spesies ini memiliki toleransi yang berbeda terhadap faktor lingkungan, dimana faktor lingkungan merupakan prasyarat untuk dapat tumbuh dan berkembang oleh suatu spesies. Suhu pada lokasi penelitian adalah $31^{\circ} \mathrm{C}-32^{\circ} \mathrm{C}$, suhu di kawasan Desa Langge Kecamatan Anggrek Kabupaten Gorontalo Utara ini relatif sedang hal ini disebabkan daerah ini bentuk pesisir yang masuk ketanjung, dan mengarah kedarat. Menurut Anisa et al., (2017) bahwa mangrove asosiasi rentan terhadap toleransi suhu lingkungan yang berkisar 31-41 ํㅡ. Faktor lingkungan tersebut sangat mempengaruhi keberadaan suatu spesies di daerah mangrove asosiasi karena merupakan prasyarat tumbuhan tersebut untuk tumbuh dan berkembang. Mangrove aosiasi agar tumbuh dan berkembang secara baik, masing-masing spesies membutuhkan persyaratan tumbuh yang berbeda sehingga memungkinkan terjadinya efisiensi alokasi energi untuk pertumbuhannya. Untuk pH tanah pada lokasi penelitian yaitu berkisar 7-7,2 \%, karena kondisi perairan di Desa Langge Kecamatan Anggrek Kabupaten Gorontalo Utara relatif belum ada pemasukan limbah-limbah, karena sedikit jauh dari pemukiman. Perbedaan nilai $\mathrm{pH}$ perairan tergantung 
pada kondisi perairan apakah sudah terjadi pencemaran yang ada disekitarnya sehingga mempengaruhi kondisi perairan. Nilai $\mathrm{pH}$ pada lokasi penelitian dapat menggambarkan kondisi $\mathrm{pH}$ yang produktif dimana kisaran nilai $\mathrm{pH}$ masih merupakan kisaran $\mathrm{pH}$ yang mendukung tumbuhnya mangrove. Hal ini sesuai pendapat Usman et al., (2013), bahwa umumnya $\mathrm{pH}$ tanah mangrove berkisar antara 6-7 satuan $\mathrm{pH}$. Salinitas pada lokasi penelitian berkisar antara 29-30 ppt, kisaran salinitas ini masih dapat mendukung pertumbuhan mangrove. Hal ini sesuai pendapat Kusmana (2005), bahwa salinitas optimum yang dibutuhkan untuk tumbuh berkisar antara 10-30 ppt. Kemudian dilanjutkan oleh pendapat Noor et al., (2012); berbagai jenis mangrove mengatasi kadar salinitas dengan cara yang berbeda-beda, dimana beberapa diantaranya secara selektif mampu menghindari penyerapan garam dari media tumbuhnya, sementara beberapa jenis lainnya mampu mengeluarkan garam dari kelenjar khusus pada daunnya.

Berdasarkan uraian diatas, spesies mangrove asosiasi mampu tumbuh di lingkungan yang memiliki salinitas rendah hingga tinggi dan setiap spesies memiliki kemampuan yang berbeda-beda dalam beradaptasi terhadap faktor lingkungan, sehingga sebaran spesies tidak selalu sama begitupun dengan spesies yang lainnya yang individunya ditemukan dalam jumlah sedikit maupun dalam jumlah yang banyak.

Tabel 3. Parameter Lingkungan

\begin{tabular}{cccc}
\hline \multicolumn{4}{c}{ Faktor Lingkungan } \\
\hline Suhu & Ph & Salinitas & Tekstur Tanah \\
\hline $31^{\circ} \mathrm{C}-32^{\circ} \mathrm{C}$ & $7-7,2 \%$ & $29-30 \mathrm{ppt}$ & $\begin{array}{c}\text { Berlumpur dan } \\
\text { Berpasir }\end{array}$ \\
\hline
\end{tabular}

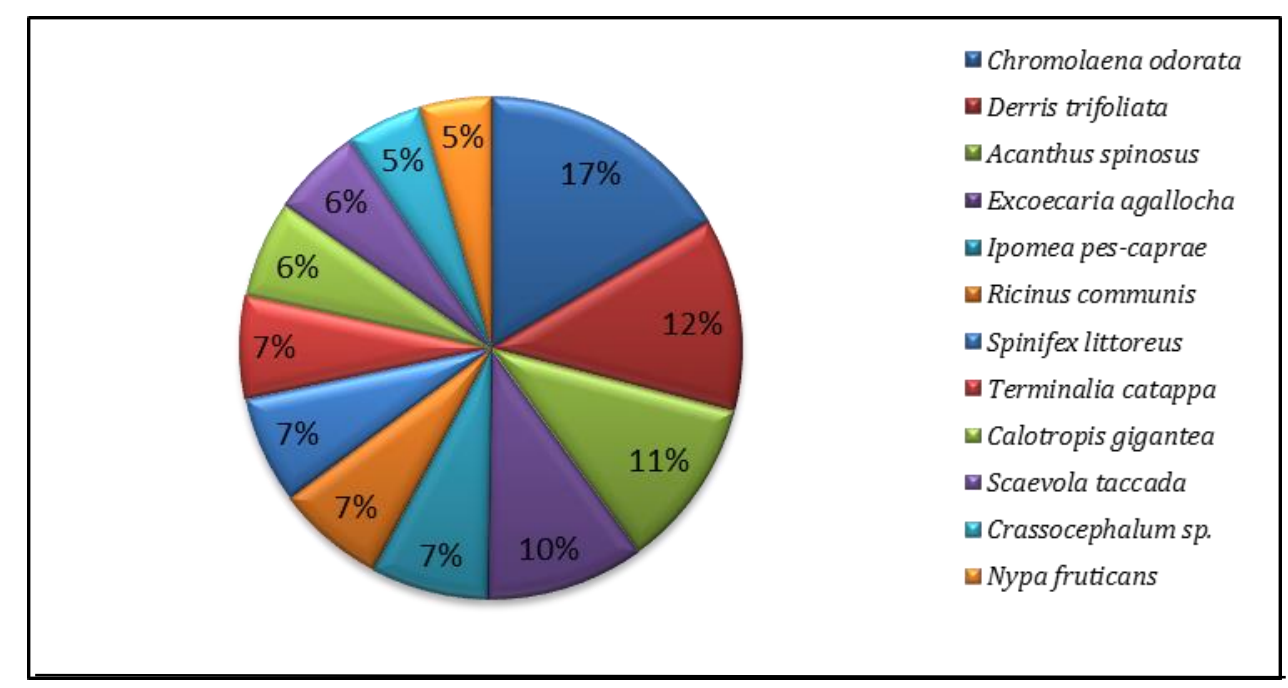

Gambar 1. Persentase INP Mangrove Asosiasi di Desa Langge

\section{Indeks Keanekaragaman}

Indeks Keanekaragaman mangrove asosiasi yang ditemukan pada kawasan mangrove Desa Langge Kecamatan Anggrek Kabupaten Gorontalo Utara. tergolong sedang hal ini dapat dibuktikan dari nilai $\mathrm{H}^{\prime}$ yang lebih dari 2. Berdasarkan kriteria Fachrul (2007) apabila nilai $H^{\prime} 1 \leq H^{\prime} \leq 3$ maka keanekaragaman jenis adalah sedang. Nilai $\mathrm{H}^{\prime}$ merupakan nilai indeks diversitas yang menentukan seberapa beragamnya suatu spesies pada daerah tertentu, suatu daerah dikatakan memiliki keanekaragaman jenis spesies sedang apabila nilai $\mathrm{H}^{\prime}$ melebihi angka 1 atau sama dengan 1 , jika nilai $\mathrm{H}^{\prime}$ lebih dari angka 3 maka keanekaragaman jenis adalah tinggi atau melimpah, namun jika nilai $\mathrm{H}^{\prime}$ yang ditemukan melebihi angka 0 namun kurang dari angka 1 maka dapat dikatakan suatu komunitas pada daerah tersebut memilki keragaman jenis spesies yang rendah. Dengan hasil indeks keanekaragaman yang didapatkan maka dapat dikatakan kawasan hutan mangrove di Desa Langge Kecamatan Anggrek
Kabupaten Gorontalo Utara ini masih dalam kondisi yang baik artinya bahwa ekosistem mangrove tersebut memiliki produktifitas yang cukup, tekanan ekologis sedang serta kondisi ekosistem cukup seimbang dimana komponen-komponen ekosistem tersedia dalam jumlah yang cukup dan berfungsi sesuai karakteristik masing-masing ekosistem, baik itu komponen biotik dan komponen abiotik. Keadaan lingkungan pada lokasi penelitian baik suhu, salinitas, dan $\mathrm{pH}$ masih dapat mendukung adanya pertumbuhan mangrove pada kawasan ini, walaupun sebagian area kawasan mangrove di wilayah ini masih terlihat adanya pembukaan lahan untuk pembangunan pemukiman dibeberapa areal kawasan mangrove yang dikarenakan campur tangan manusia yang bersifat merusak mangrove dan menurunnya jumlah individu dari suatu spesies mangrove asosiasi.

Menurut pendapat Setyawan, (2002) pengaruh besar terhadap tingkat kerusakan mangrove disebabkan oleh faktor antropogenik yaitu aktifitas 
manusia yang memanfaatkan sumber daya mangrove seperti pembukaan lahan mangrove menjadi lahan pemukiman dan pertambakkan, kemudian dilanjutkan oleh Baderan (2017) bahwa hilangnya tegakan mangrove secara otomatis berarti hilangnya pohon induk hasil benih, sementara hancurnya sebahagian hutan mangrove berarti menurunnya luasan areal yang sesuai untuk ditanam mangrove kembali. Keanekaragaman sedang pada suatu ekosistem dipengaruhi oleh keberadaan komponen jenis yang ditemukan serta perubahan vegetasi tumbuhan dilokasi penelitian akibat dari aktivitas manusia, hal ini dibuktikan dengan pengambilan mangrove sebagai kayu bakar, pembuatan patok jarring tancap, bahan bangunan, dan pembuangan sampah secara langsung di wilayah-wilayah tertentu, sehingga mengakibatkan rusaknya hutan mangrove pada lokasi ini.

Menurut pendapat Soerianegara (1972), keanekaragaman jenis sedang disebabkan oleh adanya perubahan vegetasi yang terjadi secara terusmenerus dan ditunjang oleh keberadaan unsure hara, cahaya dan air yang diperoleh vegetasi sehinggaterjadi susunan tumbuhan baik bentuk apapun jumlah jenis sesuai tempat tumbuhnya. Kerusakan hutan mangrove ini dapat menimbulkan dampak bagi kehidupan didalam kawasan maupun diluar kawasan hutan. Menurut pendapat Baderan (2017) bahwa kerusakan hutan mangrove selain berdampak pada penghidupan masyarakat di sekitar kawasan mangrove juga mengakibatkan punahnya berbagai spesies flora, fauna dan biota tertentu di dunia dan mengakibatkan hancurnya habitat hutan mangrove itu sendiri. Hal ini dapat teredam jika adanya tingkat kesadaran oleh sebagian warga yang turut berpartisipasi dalam kegiatan menanam kembali kembali tumbuhan mangrove dalam upaya rehabilitasi. Pentingnya langkah awal dalam kegiatan rehabilitasi ini untuk menunjang keberlanjutan ekosistem mangrove diwilayah ini, seperti halnya yang dikemukakan oleh Bosire, et al., (2008) yang menyatakan bahwa kegiatan rehabilitasi dan restorasi mangrove dapat mendorong kembalinya spesies-spesies mangrove dan dapat menyetarakannya dengan kawasan alami.

Tabel 4. Indeks Keanekaragaman Mangrove Asosiasi di Desa Langge Kabupaten Gorontalo Utara

\begin{tabular}{cccccc}
\hline No & Nama Spesies & Jumlah & $\boldsymbol{P i}$ & Ln Pi & Pi In Pi \\
\hline 1 & Acanthus spinosus & 117 & 0.136 & -2 & -0.271 \\
2 & Chromolaena odorata & 215 & 0.249 & -1.39 & -0.346 \\
3 & Crassocephalum sp. & 13 & 0.015 & -4.2 & -0.063 \\
4 & Calotropis gigantea & 36 & 0.042 & -3.18 & -0.133 \\
5 & Ipomea pes-caprae & 58 & 0.067 & -2.7 & -0.181 \\
6 & Ricinus communis & 49 & 0.057 & -2.87 & -0.163 \\
7 & Excoecaria agallocha & 105 & 0.122 & -2.11 & -0.256 \\
8 & Scaevola taccada & 29 & 0.034 & -3.39 & -0.114 \\
9 & Spinifex littoreus & 47 & 0.054 & -2.91 & -0.158 \\
10 & Terminalia catappa & 44 & 0.051 & -2.98 & -0.152 \\
11 & Derris trifoliata & 143 & 0.166 & -1.8 & -0.298 \\
12 & Nypa fruticans & 7 & 0.008 & -4.81 & -0.039 \\
\hline
\end{tabular}

\section{Kesimpulan}

- Berdasarkan data komposisi jenis mangrove asosiasi, di kawasan ini di temukan sebanyak 12 spesies tumbuhan mangrove asosiasi yakni Acanthus spinosus, Chromolaena odorata, Crassocephalum sp, Calotropis gigantean, Ipomea pes-caprae, Ricinus communis Excoecaria agallocha, Scaevola taccada, Spinifex littoreus, Terminalia catappa, Derris trifoliate dan Nypa fruticans.

- Berdasarkan hasil perhitungan INP menunjukkan beberapa spesies mangrove asosiasi yang menonjol yaitu spesies Chromolaena odorata dengan nilai INP sebesar 33,2 \%, kerapatan relatif sebesar 24,91\%, dan frekuensi relatif sebesar 8,3 $\%$. Spesies dengan INP tertinggi kedua dimiliki oleh spesies Derris trifoliata dengan nilai INP sebesar 24,9\%, kerapatan relatif sebesar 16,57 $\%$, dan frekuensi relatif sebesar 8,3\%. Spesies dengan nilai INP terendah dimiliki oleh spesies Nypa fruticans yaitu sebesar 9,14\%, kerapatan relatif sebesar $0,81 \%$, dan frekuensi relatif sebesar $8,3 \%$.

- Indeks Keanekaragaman mangrove asosiasi yang ditemukan pada kawasan mangrove Desa Langge Kecamatan Anggrek Kabupaten Gorontalo Utara. 
tergolong sedang hal ini dapat dibuktikan dari nilai $\mathrm{H}^{\prime}$ sebesar 2,175 .

\section{Ucapan Terimakasih}

Penulis mengucapkan terima kasih kepada Pihak Lembaga Penelitian dan Pengabdian Universitas Negeri Gorontalo yang telah mendanai melalui Penelitian Dasar Keilmuan Tahun 2017.

\section{DAFTAR PUSTAKA}

Annisa, R., Priosambodo, D., Salam, M. A., \& Santosa, S. 2017. Struktur Komunitas Mangrove Asosiasi di Sekitar Area Tambak Desa Balandatu Kepulauan Tanakeke Kabupaten Takalar Sulawesi Selatan. Bioma: Jurnal Biologi Makassar 2(1), 21-34.

Baderan K. Dewi Wahyuni, Marini S.H, Chairunnisah L, Yuliana Retonowati, 2014. Diversifikasi produk olahan buah mangrove sebagai sumber pangan alternatif masyarakat pesisir Toroseaje, Kabupaten Pohuwato, Provinsi Gorontalo, Prosiding Seminar Nasional Masyarakat Biodiversitas Indonesia Vol 1, Nomor 2, Hal 374-351.

Baderan K. Dewi Wahyuni, 2017. Distribusi Parsial dan Luas Kerusakan Hutan Mangrove di Wilayah Pesisir Kwandang Kabupaten Gorontalo Utara Provinsi Gorontalo. Jurnal GeoEco. Vol. 3, No. 1, Hal. 1-8.

Bengen, D.G. 2004. Pedoman teknis: Pengenalan dan pengelolaan ekosistem mangrove. PKSPL-IPB. Bogor

Bosire J.0, Guebas, M Walton, Crona. 2008. Functionality of Restored Mangroves: A Review. Journal Aquatik Botani. 89:251-259.

Calabon, M. S., Sadaba, R. B., \& Campos, W. L. (2019). Fungal diversity of mangrove-associated sponges from New Washington, Aklan, Philippines. Mycology, 10(1), 621.

Coastal Community Development Project-IFAD. 2013. LaporanKegiatanTahun 2013 Kabupaten Gorontalo Utara. DinasKelautan Dan PerikananKabupaten Gorontalo Utara.

Chang, Y., Chen, Y., \& Li, Y. (2019). Flow modification associated with mangrove trees in a macro-tidal flat, southern China. Acta Oceanologica Sinica, 38(2), 1-10.

De Souza Pereira, F. R., Kampel, M., \& Cunha-Lignon, M. 2016. Mangrove vegetation structure in Southeast Brazil from phased array L-band synthetic aperture radar data. Journal of Applied Remote Sensing, 10(3), 036021.

Ellison, A,M, 2008. Managing mangroves with benthic biodiversity in mind: Moving beyond roving banditry. Journal of Sea Research 59 (2008) 2-15.

Fachrul, M. F. 2007. Metode Sampling Bioekologi. Bumi Aksara. Jakarta.

Hilmi, E. 2014. Pengurangan abrasi pantai melalui peningkatan peran ekosistem mangrove sebagai jalur hijau. Pertemuan Ilmiah Tahunan (Pit) Riset Kebencanaan 2014, Surabaya 3-5 Juni 2014.

Hilmi, E. ., Sari, L.K, Setijanto. S, Kusmana . C., \& Suhendang. E, 2019. The Carbon Conservation of mangrove ekosystem in Indonesia. BIOTROPIA-The Southeast Asian Journal of Tropical Biology. 26 (3).4

Hossain, M. D., \& Nuruddin, A. A, 2016. Soil and mangrove: A review. Journal of Environmental Science and Technology, 9(2), 198.
Kerr, A.L., A.H. Bairdand A.J.Campbell, 2006. Comments on coastal mangrove forest mitigated tsunami kathiresan, $\mathrm{K}$ and $\mathrm{N}$ Rajendran. 2005. Coastal mangrove forest mitigated tsunami. (Elsevier). Estuarine, coastal and Shelf Science 65 (2005): 601606 pp. (Elsevier), 76 (2006): 539-541 pp.

Kusmana, C., Wilarso, S., Hilwan, I., Pamoengkas, P., Wibowo, C., Tiryana, T., Triswanto, A., Yunasfi., Hamsah., 2005. Teknik Rehabilitasi Mangrove. Institut Pertanian Bogor. 181 halaman.

Massel, S.R.m Furukawa, K., and Brinkman R.M, 1999. Surface wave propogation in mangrove forest. Fluid dynamic research elsevier science, Amsterdam, Vol 24, 219-249 pp.

Mueller-dombois, D. and H, Ellenberh, 1974. Aims and methods of vegetation ecology; John wiley and sons, New York.

Noor, Yus Ruslia,. M. Khazali dan IN. N. Suryadipura. 2012. Paduan pengenalan mangrove Di Indonesia. Bogor: WI-IP

Profil Desa Langge, 2015. Kecamatan Anggrek Kabupaten Gorontalo Utara.

Soares, M. L. G., Chaves, F. D. O., Estrada, G. C. D., \& Fernandez, V, 2017. Mangrove forests associated with salt flats: a case study from southeast Brazil. Brazilian Journal of Oceanography, 65(2), 102-115.

Sidiyasa, 2004. Model Pendugaan Biomassa Pohon Mahoni (Swietenia macrophyla King) di Atas Permukaan Tanah. Hutan dan Konservasi Alam Vol III No. 1 : 103 117.

Setyawan, Ahmad. 2002. Biodiversitas Genetik, Spesies, Dan Ekosistem Mangrove Di Jawa. Surakarta :Kelompok Kerja Biodiversitas Jurusan Biologi Fakultas Matematika dan Ilmu Pengetahuan Alam Universitas Sebelas Maret Surakarta.

Soerianegara, I. 1972. Ekologi Hutan Indonesia. Bogor: Departemen Management Hutan Fakultas Kehutanan IPB.

Utina Ramli, Katili Sidik Abubakar, Ibrahim Mustamin. 2012. Komposisi Dan Struktur Vegetasi Tumbuhan Mangrove Asosiasi Di Kawasan Pesisir Kwandang Kabupaten Gorontalo Utara Dan Kawasan Pesisir Managgu Kabupaten Boalemo. Laporan Penelitian. Gorontalo: Universitas Negeri Gorontalo.

Usman Laila, Syamsuddin, dan Hamzah Sri Nuryatin, 2013. Analisis Vegetasi Mangrove di Pulau Dudepo Kecamatan Anggrek Kabupaten Gorontalo Utara. Jurnal Ilmiah Perikanan dan Kelautan. Volume 1, Nomor 1, Juni2013.

Vanderwoude, C.S., J.C Davis and B. Funkhouser. 2005. Plant for National Delimiting Survey for Siaam weed. Natural Resources and Mines Land Protection Services: Queensland Government.

Wang. L., Meirong, Mo., Xiaofei, Li., Peng, L. and Wenqin W., 2010, Differentiation Between True Mangrove and Mangrove Associates Based On Leaf Traits and Salt Contents, Journal of Plant Ecology, Xiamen University, Pages 1-10. 